\title{
THE INFLUENCE OF TEMPERATURE ON THE RUSSIAN ISOLATE OF AFRICAN SWINE FEVER VIRUS IN PORK PRODUCTS AND FEED WITH EXTRAPOLATION TO NATURAL CONDITIONS
}

\section{I.P. SINDRYAKOVA1, Yu.P. MORGUNOV1, A.Yu. CHICHIKIN'1, I.Kh. GAZAEV ${ }^{2}$, D.A. KUDRYASHOV ${ }^{1}$, S.Zh. TSYBANOV1}

${ }^{1}$ All-Russian Institute of Veterinary Virology and Microbiology, Federal Agency of Scientific Organizations, 1, ul. Akademika Bakuleva, pos. Vol'ginskii, Petushinskii Region, Vladimir Province, 601120 Russia, e-mail sindryakova.irina@yandex.ru;

${ }^{2}$ Kabardino-Balkarian Reference Center of Rosselkhoznadzor (Federal Service for Veterinary and Phytosanitary Surveillance), 1, ul. 9 Maya, Nalchik, Kabardino-Balkar Republic, 360051 Russia

Received May 23, 2016

\section{Abstract}

It is known that one of the ways to spread African swine fever (ASF) virus is alimentary way (e.g., through feeding animals with contaminated feed and slaughterhouse waste products not subjected to thermal treatment, not passed veterinary and sanitary examination, and derived from epidemiologically disadvantaged regions). A variety of preserved food, such as corned beef, canned meat, bacon, etc., is made of pork products and by-products. Persistence of the virus in these products is not fully understood. For the first time we carried out studies on infectious activity of ASF virus isolates circulating in the Russian Federation, in contaminated pig products, feed, as well as in samples intended for veterinary-sanitary supervision. For this purpose, the 3-4 month-old piglets of $20-30 \mathrm{~kg}$ body weight were intramuscularly challenged with virus-containing blood. For inoculation we used ASFV isolate Volgograd-Kalach 2012 with the initial infectious titer of $7.5 \mathrm{lg} \mathrm{HAU}_{50} / \mathrm{cm}^{3}$ obtained from the National Collection of the SSINRRIVV\&M of RAAS. Three days after infection the animals were slaughtered, samples of internal organs and tissues were taken for virus isolation, and the pork was used for making corned beef, canned meat and salted lard. Blood, containing ASF virus, was also used for contamination of a compound feed and drinking water. To study effects of storage temperature on the virus infectious activity and genome detection, the samples were divided into aliquots and stored at $20-25{ }^{\circ} \mathrm{C}$ (room temperature), $4-6{ }^{\circ} \mathrm{C}$ (a common refrigerator); $-16 \ldots-20{ }^{\circ} \mathrm{C}$ (freezer). The temperatures selected for the storage of samples conform to the natural weather conditions at various seasons $\left(20-25{ }^{\circ} \mathrm{C}\right.$ in the summer, $-16 \ldots-20{ }^{\circ} \mathrm{C}$ in winter); $4-6{ }^{\circ} \mathrm{C}$ is generally maintained in storerooms or stern room in the winter months. Samples from the aliquots were taken with a 5 day intervals to determine the ASF virus titer and its genome fragments. Virus isolation was carried out in a primary culture of swine bone marrow cells for 5 days in two consecutive passages. Hemadsorption test (HAD) and real-time PCR were conducted for ASFV titer estimation and genome detection. As a result, the ASF virus was found in corned beef and lard stored at 20-25 ${ }^{\circ} \mathrm{C}$ for 16 days. At storage temperature of $4-6{ }^{\circ} \mathrm{C}$ the ASF virus was revealed in corned beef during the observation period (60 days). In frozen samples the ASFV infectious activity and DNA fragments were found throughout the entire study period (60 days). Thus, it is found that in food products and by-products from pigs slaughtered soon after ASF infecting the ASFV infectivity persists for a long time depending on the storage conditions and can pose a serious danger as a pathogen transmission factor. The data also allow to predict the temperature conditions conducive to maintaining circulation of the virus in ASF outbreaks.

Keywords: African swine fever, ASF, virus, hemadsorption test (HAD), real-time polymerase chain reaction (qPCR), epizooty, liquidation of infection focus

The epizootological survey of the African swine fever (ASF) outbreaks in the primary foci revealed that one of the main causes contributing to the introduction and spread of the virus is the use of contaminated products of pig farming $[1,2]$ or their waste $[3,4]$. This is due to neglecting the veterinary and sanitary rules and regulations, such as breaches of technological conditions of food production or the disposal rules (processing or storage) for slaughterhouse, food and household waste; violation of transportation and storage conditions for the 
finished products or feeds [5]. Thus, according to official information, meat and minced products from the territory of epidemiological concern were brought to Tsimlyansk district (Rostov Province) in 2009. The products were made from contaminated pork and not duly reprocessed [6]. In October 2009, the outbreak of ASF was recorded in the food sector of the military unit situated on the territory of the Leningrad Province. Epizootological investigation showed that the ASF virus was brought from an epidemiological region, and then spread through contaminated food waste [7]. Similar outbreaks registered in the Rostov Province (April, December 2010) and Tver' Province (May 2011) resulted from nondecontaminated kitchen waste used to feed animals [7]. This is a typical example of ASF virus dissemination ways. Similar incidents had occurred earlier in Europe (Portugal, 1957), in Cuba (1971), South America (Brazil, 1978), in Belgium (1985), and recently in Georgia (in 2007) [1].

Infection spreading remains important to understand the ASF epidemiology. In recent years, our European colleagues have investigated the roles of transport facilities, feeds, animal care items, the staff [8] or illegal butchery business [9] in ASF spreading, and rated the risk of the disease introduction via imported animals [10].

However, it is not always feasible to control and track all the possible ways of the virus spreading with pig farming products. One of the major challenges is to determine epizootologically significant trends in the diseases prevention and eradication. Underestimating some (seemingly minor) aspects leads to a substantial increase of damage. This refers to the so-called human factor of the ASF virus spreading and maintenance of the epizootic chain. Disregarding biosafety requirement or their deliberate violations can cause major epizootic ASF, and not only among domestic livestock, but also in wild populations. Given the role of anthropogenic factor in the occurrence of ASF outbreaks, the study of the ways for virus spreading are relevant.

We were the first to study the effects of temperature on the infectious activity of the ASF virus isolate, circulating in the Russian Federation, in contaminated pig products and feeds, as well as in samples for veterinary-sanitary control. The obtained data also allow predicting the temperature conditions, which contribute to formation of natural ASF foci.

The objective of this work was to evaluate the effects of temperature on the infectious activity of the African swine fever virus in porcine products, feeds and drinking water.

Technique. The 3-4 month-old Large White piglets of 20-30 $\mathrm{kg}$ in weight were challenged intramuscularly (in the middle third of the neck) with $1.0 \mathrm{ml}$ of ASFV-containing blood (the ASFV titer of $5.0 \mathrm{lg} \mathrm{HAU}_{50} / \mathrm{cm}^{3}$ ). A Volgograd-Kalach 2012 isolate from National Collection of the All-Russian Institute of Veterinary Virology and Microbiology (RIVV\&M of RAAS) was used (initial titer of $7.5 \mathrm{lg} \mathrm{HAU}_{50} / \mathrm{cm}^{3}$ ). Three days after infection the animals were slaughtered, samples of swine offal (internal organs and tissues) were taken for virus isolation, and the pork was used for making corned beef, canned meat and salted lard.

Corned beef was made from the meat of infected piglets using a wet salting method. Canned meat was prepared in compliance with RF State Standards (GOST 32125-2013 «Canned meat. Stewed meat. Specifications». The fat was processed by dry salting in compliance with common technology (OST 38-85 49 «Products of pork fatback. Specifications»).

The compound feed composition (in \%) used for the ASFV infectious activity evaluation and genome detection was as follows: barley -40 , wheat -21 , oats -10 , wheat bran -10 , barley flour -11 , cottonseed meal -5 , softwood 
flour -0.5 , chalk -0.7 and sodium chloride -0.1 . Feed samples (10 g each) were contaminated with the virus-containing blood (Volgograd-Kalach 2012 isolate) pre-diluted in the MAH (milk albumin hydrolyzate) medium (1:10) to a final infectious titer of $7.0 \mathrm{lg} \mathrm{HAU}_{50} / \mathrm{cm}^{3}$, and air-dried for 8-12 hours. To test

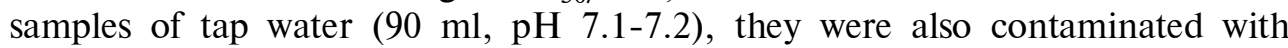
blood containing Volgograd-Kalach 2012 isolate $(10 \mathrm{ml}$ inoculum, the infectious titer of $7.5 \mathrm{lg} \mathrm{HAU}_{50} / \mathrm{cm}^{3}$ ).

All the specimens were divided into sets for further storage under different temperature conditions: 22-25 ${ }^{\circ}$ (room temperature); 4- $6{ }^{\circ} \mathrm{C}$ (household refrigerator); $-16 \ldots-20^{\circ} \mathrm{C}$ (the temperature of a freezing camera). With a 5 dayintegrals, the viral titers were analyzed by a hemadsorption test (HAT) and DNA detection in the real-time PCR.

The virus was isolated in primary culture of porcine bone marrow (PBM) after two passages for 5 days. The inoculated cell cultures were incubated at $37.0 \pm 0.5{ }^{\circ} \mathrm{C}$ for $3-5$ days. The hemadsorption assay was performed using a conventional technique [11]. The viral titers $\left(\mathrm{HAU}_{50} / \mathrm{cm}^{3}\right)$ were calculated by the Reed-Müench method.

A kit for Real-Time PCR Detection of the African Swine Fever Virus DNA (RIVV\&M of RAAS) and protocol were according to the instructions [12].

Results. The temperatures used for the storage are consistent with the natural weather conditions for different times of year, particularly, $22-25{ }^{\circ} \mathrm{C}$ are typical of summer in the central Russia, $-16 \ldots-20{ }^{\circ} \mathrm{C}$ are typical of winters, and $4-6{ }^{\circ} \mathrm{C}$ are generally maintained in storerooms at pigsties in winter.

It is known that all virulent ASFV strains usually possess hemadsorbing properties, which reflect their infectious activity in animals [13]. Therefore, when interpreting the results, we regarded hemadsorption as the confirmation for the presence of the infectious virus.

1. Time periods for detection of African swine fever virus and its genome fragments in the porcine products stored at $22-25{ }^{\circ} \mathrm{C}$

\begin{tabular}{l|c|c}
\hline \multicolumn{1}{c}{ Sample } & HAT & Real time PCR \\
\hline Corned meat & $+(16$ days $)$ & $+(28$ days $)$ \\
Fat & $\mathrm{N} / \mathrm{T}$ & $+(28$ days $)$ \\
Heart & $\mathrm{N} / \mathrm{T}$ & $+(28$ days $)$ \\
Kidneys & $\mathrm{N} / \mathrm{T}$ & $+(28$ days $)$ \\
Liver & $+(16$ days $)$ & $+(56$ days $)$ \\
Canned stew meat & - & - \\
N o t e. HAT - hemadsorption test. N/T - not tested; "+" \\
and "-" are positive and negative results, respectively.
\end{tabular}

In food products, stored at room temperature, infectious ASFV was detected from day 1 to day 16 (the maximum storage period for samples with positive results). The DNA fragments were detected up to day 28 , and in the liver up to day 56 (Table 1). This is due to the active autolytic and hydrolytic processes taking place at $22-25^{\circ} \mathrm{C}$. As a result, serological tests for such samples are ineffective. It should be taken into account that long-term (over 12 hours) storage of meat products at positive temperatures, except for the fresh refrigerated products (presales storage), is forbidden by sanitary rules and regulations. The viral genome and its fragments were not detected in canned stew meat prepared from infected porcine meat during the entire study (56 days) (see Table 1).

2. Titers of African swine fever virus $\left(\mathrm{lg} \mathrm{HAU}_{50} / \mathrm{cm}^{3}\right)$ and its genome detection by real time $\mathrm{PCR}$ in the porcine products stored at 4-6 ${ }^{\circ} \mathrm{C}$

\begin{tabular}{l|c|c|c|c|c|c|c|c}
\hline \multicolumn{1}{c}{ Product } & $n$ & Day 1 & Day 10 & Day 20 & Day 30 & Day 40 & Day 50 & Day 60 \\
\hline Corned meat & 14 & $3.0 /+$ & $3.0 /+$ & $3.0 /+$ & $2.5 /+$ & $2.0 /+$ & $2.0 /+$ & $1.5 /+$ \\
Salted pork fatback & 14 & $0.0 /+$ & $0.0 /+$ & $0.0 /+$ & $\mathrm{N} / \mathrm{T} /+$ & $\mathrm{N} / \mathrm{T} /+$ & $\mathrm{N} / \mathrm{T} /+$ & $\mathrm{N} / \mathrm{T} /+$ \\
Canned stew meat & 14 & $0.0 /-$ & $0.0 /-$ & $0.0 /-$ & $\mathrm{N} / \mathrm{T} /-$ & $\mathrm{N} / \mathrm{T} /-$ & $\mathrm{N} / \mathrm{T} /-$ & $\mathrm{N} / \mathrm{T} /-$ \\
N o t e. Porcine bone marrow culture and the hemadsorption test (HAT) were used. N/T - not tested; "+" and \\
"-" are positive and negative results, respectively.
\end{tabular}

In a household refrigerator $\left(4-6{ }^{\circ} \mathrm{C}\right)$ (Table 2), ASFV remained infec- 
tious in corned meat at the titers of 3.0-1.5 $\mathrm{lg} \mathrm{HAU}_{50} / \mathrm{cm}^{3}$ during 60-day study, while in salted fat (sowbelly) it was not found. The ASFV genome persisted in sowbelly and corned meat during the entire study (60 days) at 4-6 ${ }^{\circ} \mathrm{C}$. Note, no ASFV was found with no genome fragments identified in canned meat (see Table 2) due to long-term exposure to high temperatures, used according to GOST, which apparently destroys both ASFV and its DNA.

3. Titers of African swine fever virus $\left(\lg \mathrm{HAU}_{50} / \mathrm{cm}^{3}\right)$ and its genome by real time PCR in contaminated feed and water

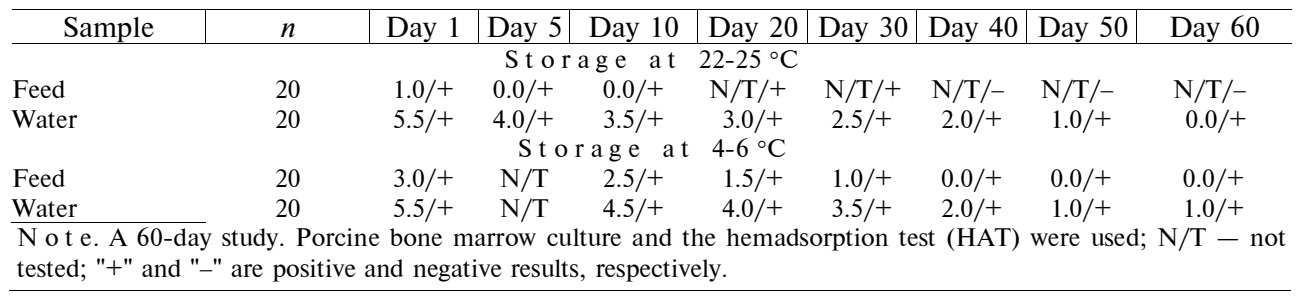

In the box room used for storing feed and tap water samples, the $\mathrm{Cl}$ concentration in air was $0.8 \mathrm{mg} / \mathrm{m}^{3}$ at $50-70 \%$ humidity. In this, at room temperature, ASFV persisted in the compound feed for up to 5 days (Table 3). Probably the ASFV inactivation, observed later, is due to the effects of numerous chemical ingredients in the feed and its high adsorption capacity. In water samples, the infectious ASFV was isolated within 60-day period. Starting from day 40, the ASFV genome could not be detected in the compound feed. It may be also due to the effects of virucidal chemical components of feed additives. At room temperature, the infectious ASFV in tap water was isolated during the entire study (60 days).

At $4-6{ }^{\circ} \mathrm{C}$, ASFV was isolated at 3.0-1.0 $\mathrm{lg} \mathrm{HAU}_{50} / \mathrm{cm}^{3}$ from contaminated compound feed on day 1 to day 30 of 60 -day study. In water samples, the virus was isolated for 60 days at 5.5-1.0 Ig $\mathrm{HAU}_{50} / \mathrm{cm}^{3}$ depending on the storage time. The ASFV genome was detected in the contaminated compound feed and tap water during 60-day study. Therefore, at 4-6 ${ }^{\circ} \mathrm{C}$, the contaminated compound feed and water may pose a risk of infection for more than 30-60 days.

The ASFV remained infectious and the viral DNA fragments were detected during the entire study (60 days) in meat products, offal, feed and water stored at negative temperatures.

Thus, this paper is the first study on how the temperature affects the ASFV isolate, circulating in the Russian Federation, in the products of pig farming and feed. These findings are also important due to the fact that currently the disease outbreaks are being registered in previously ASF-free regions, and both in domestic pigs and in wild boars.

There are multiple possible ways of the ASFV spreading, such as feeding animals with food waste [2, 13], using contaminated transport facilities and care items, feeds, or staff errors [8, 14]. In Denmark and the Netherlands, the transport facilities were recognized as one of the most important ways the classical swine fever (CSF) can spread with [15, 16]. The transmission of animal diseases through transport facilities used in specific regions or countries $[15,16]$ or through illegal butchery business [9] was evaluated. Other studies carried out in Denmark, the Netherlands, the USA and the UK, were aimed at identifying vulnerable populations of animals when feeding them with food waste [17-19]. Recent publications have discussed the risk of ASFV introduction when importing pigs [10]. Illegal pork trade and the use of food waste in the animals feeding are recognized the most significant anthropogenic factors of the ASFV dissemination [20-22]. Moreover, a large number of private farms with their low bi- 
osafety level poses additional risks of the disease occurrence and dissemination

Previously, Spanish researchers showed that ASFV could persist for several weeks or months in the frozen [23], freshly prepared or raw, as well as salted dried meat [24, 25], which was in line with our findings

When extrapolating our findings on natural and agricultural objects, it should be focused on the need to observe basic sanitary rules, given the fact that the virus can remain virulent for more than 2 weeks under favorable environment. Among violations, control over which is not often covered by the scope of the Veterinary Services competence and is not appropriately regulated, are i) untimely garbage collection in the recreation areas for citizens or the lack of decent household waste storage places, ii) the spontaneous waste landfill deposits arising along roads, in the outskirts of human settlements or in forest areas, iii) feeding domestic pigs with food waste not subjected to a heat pre-treatment, iv) illegal utilization and storage of slaughterhouse wastes. All these practices lead to infection of pigs and the emergence of new outbreaks of ASF.

Thus, in offal and food products derived from animals suffering from African swine fever (ASF), and in water contaminated with ASFV, the infectious virus and its genome can persist at $22-25^{\circ} \mathrm{C}$ (temperature in the spring, summer and autumn) for more than 2 months. Therefore, this indicates their high infectious activity in the diseases foci and the probable contribution to the infection dissemination beyond the identified center. If an ASF outbreak occurs in the winter, the time when the ASFV infectious activity remains high and the infection can spread outwards prolongs according to the time of exposure to negative temperatures. Considering that the ASFV DNA persists in compound feed for more than 60 days, feed logistics must exclude any possible movements to the ASF-free areas. The pork meat treatment according to GOST 32125-2013 eliminates any possibility for ASFV and its genome fragments to persist due to complete sterilization. Places of unauthorized dumping of household and food waste, unregistered or unequipped objects of their disposal on the territory of epizootic concern or in the epizootic foci, as not subjected to anti-epizootic measures and routine disinfection, may become the regions of the ASFV conservation

\section{REFEREN C ES}

1. Mur L., Martinez-Lopez B., S a nchez-Vizcaino J.M. Risk of African swine fever introduction into the European Union through transport-associated routes: returning trucks and waste from international ships and planes. BMC Vet. Res., 2012, 8: 149 (doi: 10.1186/1746-6148-8-149).

2. Beltran-Alcrudo D., Lubroth J., Depner K., De La Rocque S. African swine fever in the Caucasus. FAO Empres Watch, 2008, April: 1-8.

3. D a n kvert S.A. Epizooticheskaya situatsiya v Rossiiskoi Federatsii po afrikanskoi chume svinei (po sostoyaniyu na 1 oktyabrya 2013 goda) [African swine fever in the Russian Federation - epizootic situation (dated October 01, 2013)] (in Russ.). Available http://www.fsvps.ru/fsvps/iac/report.html. No date.

4. M a k a rov V.V. Afrikanskaya chuma svinei [African swine fever]. Moscow, 2011 (in Russ.).

5. Gogin A., Gerasi mov V., Malogolovkin A., Kolbasov D. African swine fever in the North Caucasus region and the Russian Federation in years 2007-2012. Virus Res., 2013, 173: 198-203 (doi: 10.1016/j.virusres.2012.12.007).

6. V 1 a s o v N.A. O razvitii epizooticheskoi situatsii po ACHS na territorii Rossiiskoi Federatsii [On ASF epizootic situation in the Russian Federation] (in Russ.). Available http://www.fsvps.ru/fsvps-docs/ru/iac/2009/files/iac_asf.pdf. No date.

7. O realizatsii meropriyatii po likvidatsii ACHS na territorii Rossiiskoi Federatsii [On the ASF eradication in the Russian Federation] (in Russ.). Available http://www.fsvps.ru/fsvpsdocs/ru/iac/2011/files/asf_2011-06-29.pdf. No date.

8. Morilla A. Las enfermedades virales emergentes de los cerdos. Ciencia veterinaria, 2003, 9: 197-219.

9. Wooldridge M., Hartnett E., Cox A., S e m a n M. Quantitative risk assessment case study: smuggled meats as disease vectors. Rev. Sci. Tech., 2006, 25: 105-117 (doi: 
10.20506/rst.25.1.1651).

10. Mur L., Martinez-Lopez B., Martinez-Aviles M., Costard S., Wie la nd B., Pfe iffer D.U., S a n che z-Vizcaino J.M. Quantitative risk assessment for the introduction of African swine fever virus into the European Union by legal import of live pigs. Transbound. Emerg. Dis., 2012, 59: 134-144 (doi: 10.1111/j.1865-1682.2011.01253.x).

11. Carrascosa A.L., B ustos M.J., d e Le on P. Methods for growing and titrating African swine fever virus: field and laboratory samples. In: Current Protocols in Cell Biology. Wiley, Hoboken, 2011. Suppl. 53. Unit 26.14: 26.14.1-26.14.25 (doi: 10.1002/0471143030.cb2614s53).

12. Instruktsiya po primeneniyu «Test-sistemy dlya vyyavleniya DNK virusa ACHS metodom PTSR $v$ real'nom vremeni» [qPCR kit for indication ASFV DNA: instruction]. Pokrov, 2013 (in Russ.).

13. Morgunov Yu.P., Petrov Yu.I. Problemy biologii produktivnykh zhivotnykh, 2010, 4: 104111 (in Russ.).

14. EFSA AHAW Panel (EFSA Panel on Animal Health and Welfare). EFSA Journal, 2015, 13(7): 4163 (doi: 10.2903/j.efsa.2015.4163).

15. S p i c kle r A.R., R o th J.A. African swine fever. In: African swine fever. Iowa State University, College of Veterinary Medicine, 2011.

16. B ro ns voort B.M.D., A lb a n L., Gre in e r M. Quantitative assessment of the likelihood of the introduction of classical swine fever virus into the Danish swine population. Prev. Vet. Med., 2008, 85: 226-240 (doi: 10.1016/j.prevetmed.2008.01.013).

17. de Vos C.J., S a t k a m p H.W., N i e le n M., Hu i r n e R.B. Scenario tree modeling to analyze the probability of classical swine fever virus introduction into member states of the European Union. Risk Analysis, 2004, 24: 237-253 (doi: 10.1111/j.0272-4332.2004.00426.x).

18. Adkin A., England T., Hall S., Coburn H., Marooney C.J., Seaman M., C o o p e r J., H a r t n e t t E. Estimating the risk of exposure of British livestock to footand-mouth disease associated with the importation of ship and aircraft waste. Vet. Rec., 2008, 163: 235-240 (doi: 10.1136/vr.163.8.235).

19. Cors o B. Likelihood of introducing selected exotic diseases to domestic swine in the continental United States of America through uncooked swill. Rev. Sci. Tech., 1997, 16: 199-206 (doi: 10.20506/rst.16.1.1005).

20. G a le P. Risks to farm animals from pathogens in composted catering waste containing meat. Vet. Rec., 2004, 155: 77-82 (doi: 10.1136/vr.155.3.77).

21. Iglesias I., Mucoz M.J., Montes F., Pérez A., Gogin A., Kolbasov D., de la Torre A. Reproductive ratio for the local spread of African swine fever in wild boars in the Russian Federation. Transbound. Emerg. Dis., 19 FEB 2015 (doi: 10.1111/tbed.12337).

22. Costard S., Jones B.A., Martínez-Lypez B., Mur L., de la Torre A., Martínez M., Sánchez-Vizcaíno F., Sánchez-Vizcaíno J.M., Pfeif fe $r$ D.U., Wieland B. Introduction of African swine fever into the European Union through illegal importation of pork and pork products. PLoS ONE, 2013, 8(4): e61104 (doi: 10.1371/journal.pone.0061104).

23. Adkin A., Coburn H., England T., Hall S., Hartnett E., Marooney C., W o o ld ridge M., Wa t s o n E., C o o p e r J., C ox T., S e a m a n M. Risk assessment for the illegal import of contaminated meat and meat products into Great Britain and the subsequent exposure of GB livestock (IIRA): foot and mouth disease (FMD), classical swine fever (CSF), African swine fever $(A S F)$, swine vesicular disease (SVD). New Haw, Veterinary Laboratories Agency, 2004.

24. Sá n che z-Vi z c a íno J.M., M u r L., M a r tín e z-Lypez B. African swine fever (ASF): five years around Europe. Vet. Microbiol., 2013, 165(1-2): 45-50 (doi: 10.1016/j.vetmic.2012.11.030).

25. Scientific Opinion on African swine fever. EFSA Panel on Animal Health and Welfare (AHAW). EFSA Journal, 2010, 8(3): 1556 (doi: 10.2903/j.efsa.2010.1556).

26. Mebus C., Arias M., Pine da J., Tapiador J., House J., Sánchez-Vizcaíno J.M. Survival of several porcine viruses in different Spanish dry-cured meat products. Food Chem., 1997, 59(4): 555-559 (doi: 10.1016/S0308-8146(97)00006-X).

\section{Events \\ $6^{\text {th }}$ EUROPEAN CONGRESS OF VIROLOGY}

(19-22 October 2016, Hamburg, Germany)

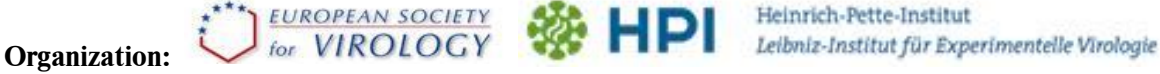

The European Congress of Virology is the premier virology conference in Europe and is organized by the European Society for Virology (ESV). ECV2016 will bring together both junior and senior scientists, and will cover all aspects of virus research including basic, clinical, veterinary and plant virology.

Contacts: http://www.hpi-hamburg.de, ecv2016@hpi.uni-hamburg.de

Information: http://www.globaleventslist.elsevier.com/events/2016/10/6th-european-congress-of-virology/ 